\title{
I am a Black Woman
}

\section{Rheanna Rookwoud}

Toronto, ON

My name is Rheanna Rookwood. I was born in Toronto, Ontario. I am 17 years old. Currently, I am a high school student and I am in grade 11. At my high school, I am involved in many programs such as CAPUT (student counsel), Afro-can, Mental Health \& Wellness Committee and OCI talks. In CAPUT, I am the director of social affairs and an overseer of social events. In the Afro-can club, we discuss issues and achievements within the black community and host events. In the Mental Health \& Wellness Committee, we plan events to help students decompress and we also focus on lifting individual's spirits. OCl talk is a platform used to talk about topics that students are interested in for example anime, colorism, racism, body image, and violence within the community.
Keywords

Black women, racism, empowerment, poetry 


\title{
How I envision my future
}

In my future, I envision myself as having my own mental health practice. My practices will be geared towards people of colour and for all ages. I would like to have two practices, one to be based in Canada and the other in the West Indies. I aspire to open my practices because I want to create a space that encourages people to open up about their emotions and not feel judged. I also envision myself being a mentor for Black Women. I want to help Black Women to feel and know that they are capable of doing anything they put their mind to.

\section{How I envision my future (based on my essay, The Treatment of Black Women)}

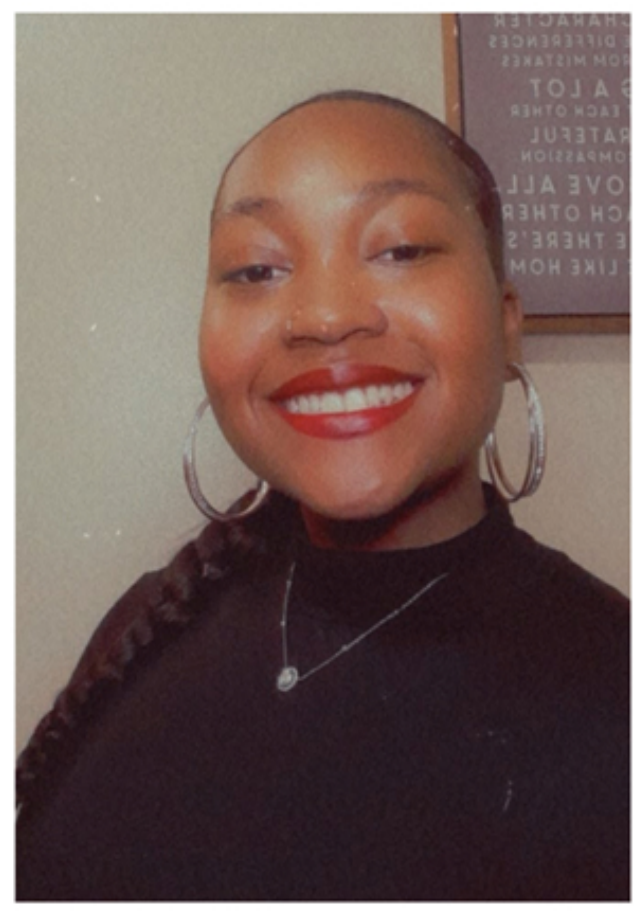

\author{
In the future, I see Black \\ Women being more comfortable in \\ their skin. I see us being more \\ accepting and appreciating of \\ ourselves and our rich culture. I \\ picture Black Women becoming more \\ knowledgeable of our history and \\ using that information to support \\ each other and to strive to be \\ the best we can be.
}




\section{I am a Black Woman}

I am a Black Woman. I am proud of who I am and I

have great admiration for strong Black Women

who do not put themselves in a box and conform

to what society wants them to be. They are in

control of their own lives and have voices. They

believe in change and are setting standards that

represent what I strive to achieve.

The eyes of

Eartha Kitt

The voice of

Ella Fitzgerald

The legs of

Noami Campbell

The Moves of

Izzy Odigie

The Athleticism of

Wilma Rudolph

Strength of

Serena Williams 
Style of

Aaliyah

Flow of

Missy Elliot

Courage of

Winnie Mandela

Grace of

Michelle Obama

Stance of

Rosa Parks

I am the past, present and future

I am an empowered Black

Woman

I never give up when things

get too hard

When I walk by people they bow to their knees, because I am a queen. 
All these Black Women are from different generations but convey similar messages. They make it known that they can not be defined by their skin tone or their physical attributes. They have all made a name for themselves by being who they are; strong, confident, powerful, and insightful women who have made a difference in society. In this piece, I want to highlight the struggles of Black Women and show that Black Women are self-assured and driven. 


\section{Introduction}

Why are Black women disrespected so much? This question I could never understand. Maybe it is our clothes or attitude. Maybe it is society assuming we should act a certain way. Maybe the issue lies deep within our history. For years, Black women have been viewed as objects. They are judged by their appearance, and not acknowledged for their contributions to society. Black women are not getting the credit that they deserve from most White people. Most White people viewed Black women as being illiterate and the lower class. The era where Black women were enslaved and Whites domination contributes to the denigration of Black women in contemporary times.

The denigration of Black women dated back in history since the onslaught of colonization. In 1789, a Black woman named Sarah (previously known as Saartjie) Baartman was born at the Eastern Cape (formerly known as Gamtoos River) in the continent of South Africa (Parkinson, 2016). She was dehumanized, treated like an object and was greatly disrespected. Sarah Baartman was the first Black woman to be exposed to human sexual trafficking (Parkinson, 2016). At the age of sixteen, Ms. Baartman was sold into slavery. In October 1810, Ms. Baartman immediately began working on stage shows where she was exploited daily and ordered to perform half-naked. Her blackness, unique shape and exotic facial features caused her to be victimized. The White people called her an ape, touched her inappropriately, ordered her to growl and howl, and told her to walk like a white woman (Kechiche, 2020). The Whites who visited her to 
experience her exotic features only paid to see her buttocks. On November 24, 1810, Sarah Baartman allegedly signed an agreement with a physician named William Dumlop to move to England. Sarah Baartman was given false hope; she was promised a good life. She was told that she would earn enough money to own a farm and that she would be able to go back home whenever she pleases. This was not the case, she was never allowed to go back home. This treatment caused her to decline mentally and physically. Even in her death, she was exposed; her remains were placed on display in a museum. The scientists dismembered her remains. They removed her brain and weighed it. They also made a mould of her body and illustrated her body parts. It took over 100 years for Sarah Baartman to be properly laid to rest. The role that racism played in Ms. Baartman's life is that in life and death she did not profit, nor was she shown respect. She was judged based on her appearance.

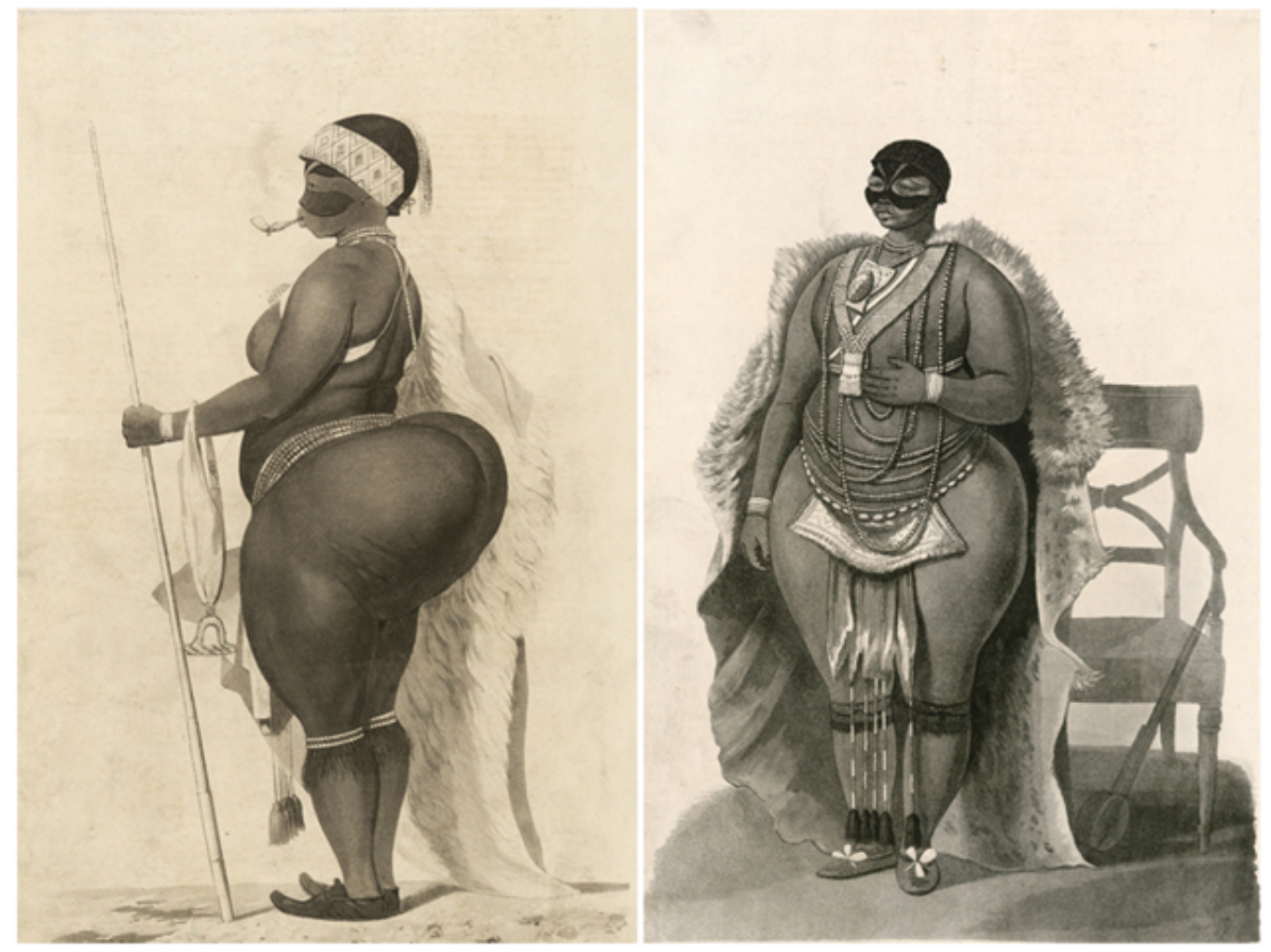




\section{Treatment of Black Women in Contemporary Times and the Influence of Social Media}

Serena Williams, an American professional tennis player, is a modern-day example of a Black woman who has been subjected to objectification. During one of Serena's competitions, her coach was allegedly giving her hand gestures throughout the game. The chair umpire, Carlos Ramos interpreted the hand gestures for illegal coaching. Serena Williams tried to explain to the chair umpire that the hand gestures were indicating signs of encouragement, but he saw it as cheating. Serena Williams' push back led to her getting humiliated by the crowd, losing points, penalized from the game, and fined 17,000 dollars. When Serena Williams' white counterparts openly expressed themselves, they were not penalized as harshly. How can a thumbs-up be a sign of illegal coaching? I believe that she was treated unfairly, and it demonstrates how even in the world of sports, Black Women are treated differently from their white peers.

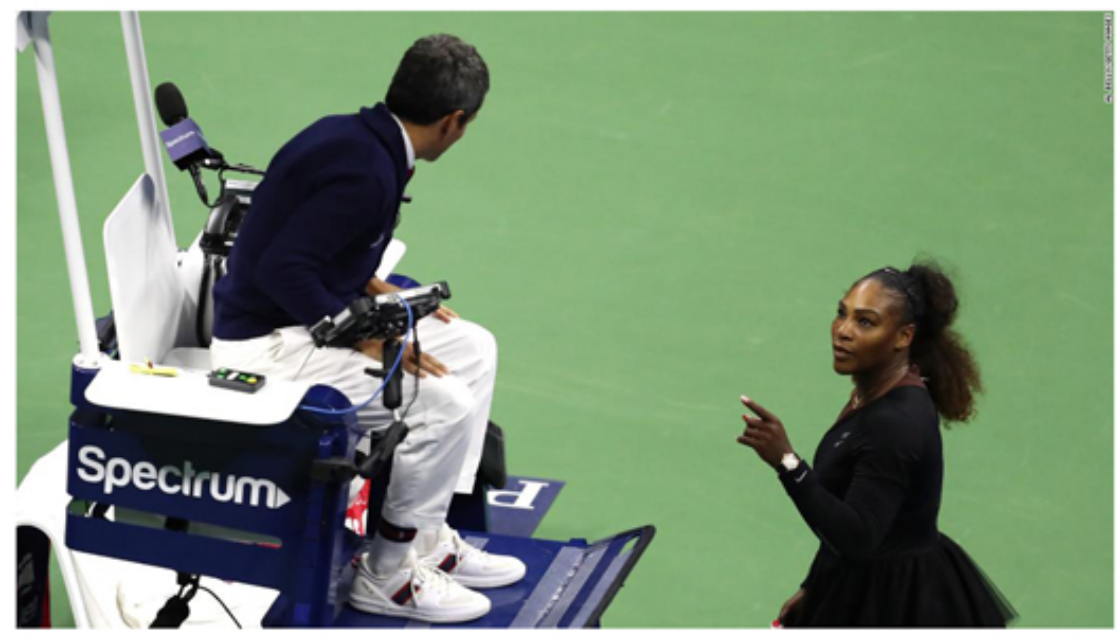

Serena Williams and Carlos Ramos 
Like Ms. Baartman and Ms. Williams, I also have been subjected to objectification and shown a lack of respect. In one instance, a Whiteman on the

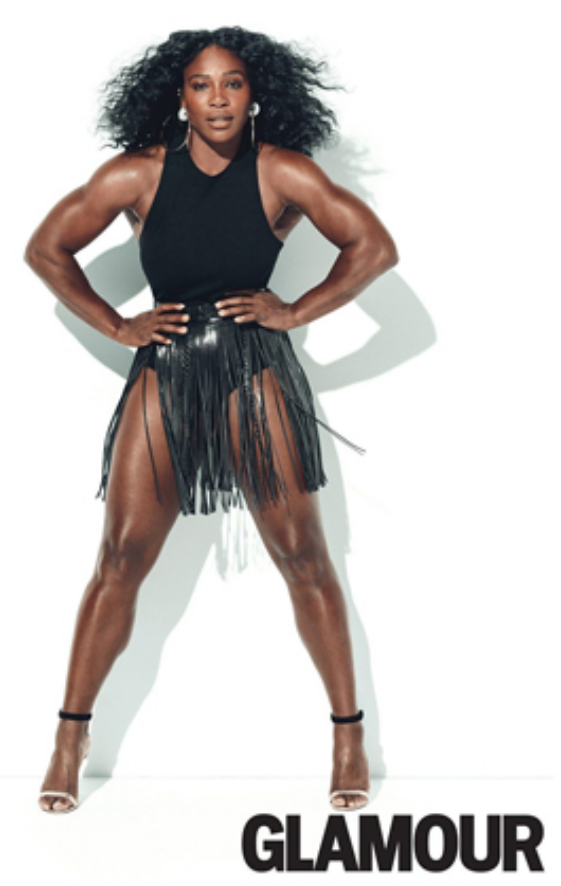

Williams on the 2015 cover of Glamour Magazine

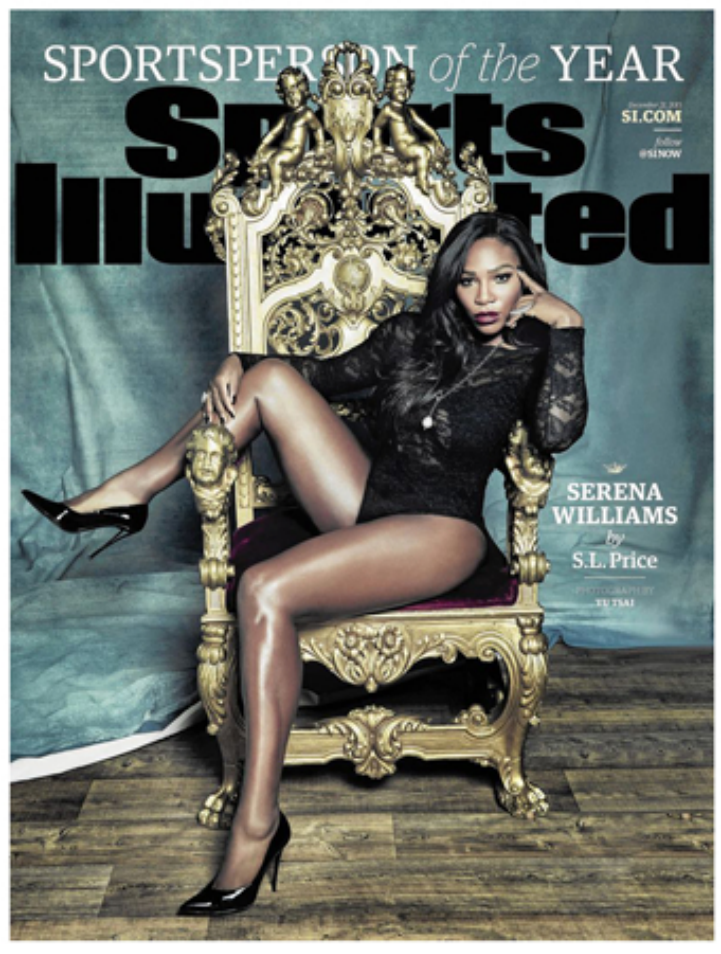

Williams on the 2015 cover of Sports Illustrated Magazine streetcar called my friend and I 'Black bitches,' and other very inappropriate racial slurs. He did not know us and nobody on the streetcar defended us. We were so frightened that we just got off the streetcar. I felt so disrespected and misjudged, the Whiteman's behaviour was so unjust and unnecessary.

As Ms. Baartman did not profit from her work, so did a Black Woman named Esther Jones. Esther Jones, also known as Gertrude Saunders, was born in Chicago, Illinois. She was a child performer and she was known as 'Baby Esther.' She was the first Black woman to develop the 'Baby Style' (Boop-Oop-aDoop) (Angbeletchy, 2020). A White woman named Helen Kane saw her performances in a Harlem night club and copied her style. Helen Kane became popular from Esther Jones' persona (Angbeletchy, 2020).

\section{For example, the cartoon} character Betty Boop was always known as a White cartoon character. Originally, Betty Boop was illustrated as being both Black and White. The style and voice of Betty Boop was derived from a Black Woman named Esther Jones. The profits from the Betty Boop series went to the 
went to the White Betty Boop, Helen Kane, and the animator, Max Fleisher (Dokosi, 2020). The Black Betty Boop and Esther Jones were forgotten. Esther Jones was just one of many Black women who were denied the credit, respect and were subjected to historical cultural appropriation.
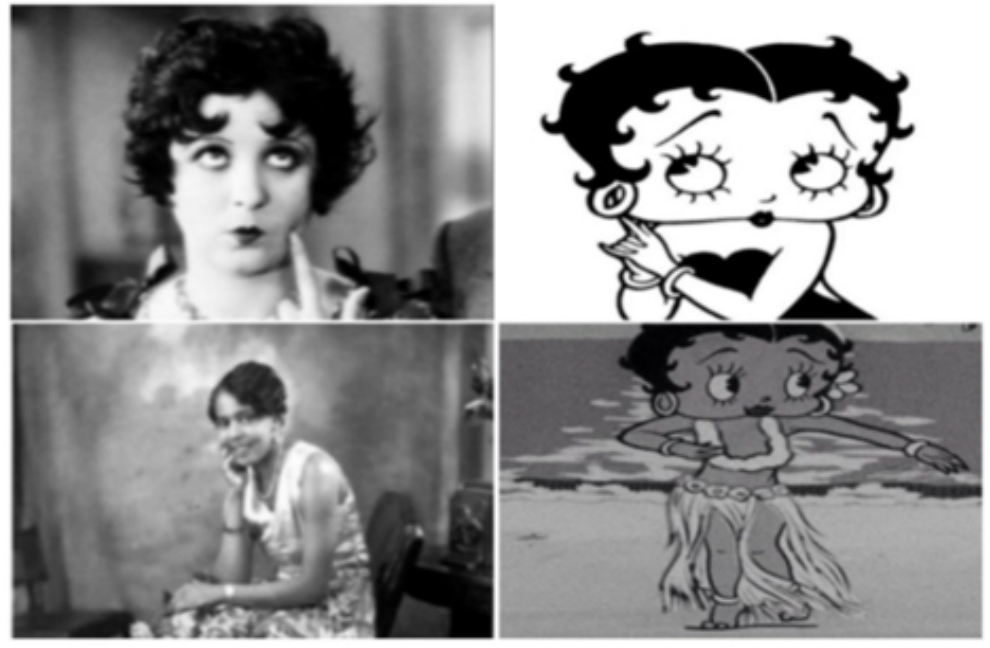

Many things that are exclusive to Black women have been stolen and rebranded by white social media. White media tends to act as though everything they do is original but in some cases it was already created by Black women.

Helen Kane, also known as White Betty Boop (top); Esther Jones, also known as Black Betty Boop (bottom)
For instance, Kim Kardashian started to wear 'box braids' but called them 'boxer braids.' She later apologized for renaming 'box braids' to 'boxer braids'. I felt that her apology was insincere and that she had to apologize because of her huge social media presence. She currently has over 183 million followers on Instagram. The widespread media backlash played a vital role in her apology. She would have lost credibility and the respect from her fans for taking credit for renaming a hairstyle that already has its own name. This may be a small matter to the White community, but to the Black community it is a big issue. It is theft to claim something that does not belong to you. And with social media heavily involved in the 'boxer braids' issue, it may highlight more existing tension between the Black and White communities. The Black community will see the issue as a person adopting parts of a culture that is not their own which is cultural appropriation. The White community will view this as 
they are being respectful to the elements of their culture which is cultural appreciation. Cultural appreciation tends to be a nicer way of allowing cultural appropriation to slide and some White people take full advantage of that.

Social media also has a tendency of making existing ideas look like it is something new. But, in $r$ eality, it has already been used, and will continue to be an important part of Black hair care and culture long after White media has abandoned this "trend".

To be honest, it seems like White women are getting attention for their darkened skin and textured hair instead of Black Women. It is trending for White women to have Black features because they are ones profiting and getting all the approval from social media. This approval is due to and in some cases has resulted

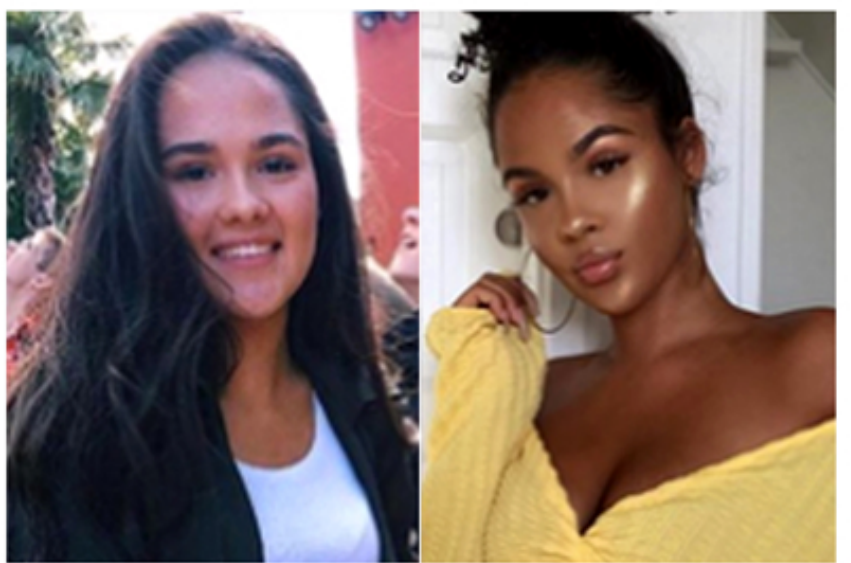

Emma Hallberg with and without makeup in 'blackfishing'. Blackfishing happens when a person alters their appearance to look Black. For instance, a Swedish influencer named Emma Hallberg has been accused of blackfishing. She portrayed herself as a Black woman by applying dark colored makeup and tanning lotion to make her skin appear darker. Ms. Hallberg texturized her hair to look racially ambiguous. She also enjoyed free publicity and endorsement from Instagram pages that were geared towards a Black audience. Emma Hallberg has gotten a lot of negative comments for portraying herself as someone that she is not. Many of her Black female followers felt like they were blackfished because she misled them into believing she was a Black Woman. She also misguided the press; the press endorsed her as a Black Woman. The result of being blackfished has a negative impact on the Black community because it creates distrust and the need for verification becomes more important. 
Black women are also subjected to the term colourism and texturism. The terms have often been used to categorize Black women. Colourism and texturism convey the message of what is considered as accepted and not acceptable. It aims to divide Black Women because it causes them to believe that is the only way they can be a part of society. The movie, School Daze (1988), for example, displays colourism and texturism. The Black women that had dark skin were seen as having the bad hair and were called 'jigaboos'. Jigaboos is a discriminating term used to describe Black people. Whereas light skinned women were seen as having good hair and considered superior beings. This movie shows how Black women are defined as beautiful if they have straight hair and are light skinned. It shows how much internalized racism Black women go through by trying to make ourselves look like what White society demands that we look like. This is also a direct result of external racism. While Emma Hallberg is commended for her unnatural Blackness, Sarah Baartmen was ridiculed for her natural Black features.

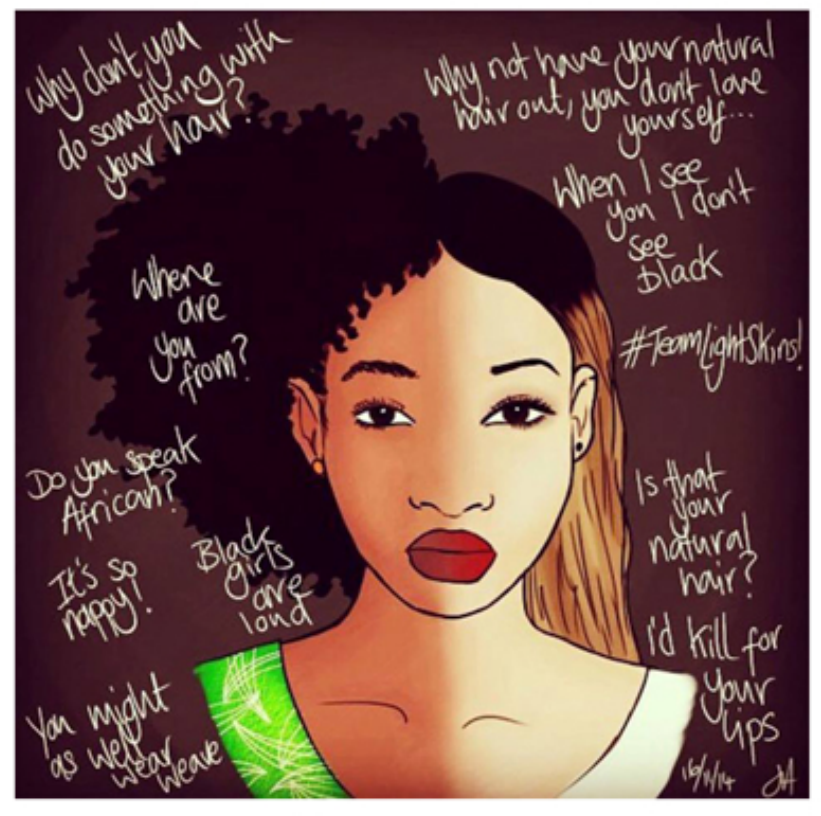

I feel very strongly about the words colourism and texturism because they are negative terms that are geared towards dividing Black women or pitting them against each other. It causes Black women to be spiteful against each other when in reality Black women should be proud of who they are and empower each other.

Why are Black Women looked upon like this and why do some Black men allow this to happen? In my 
opinion, one of the biggest problems is that the White society only saw Black women as being typical and incapable of succeeding. The other part of the problem is that some popular Black male figures, such as Matthew Knowles and Gilbert Arenas do not support Black women, instead they choose to degrade us. Black women should be viewed as queens and capable individuals.

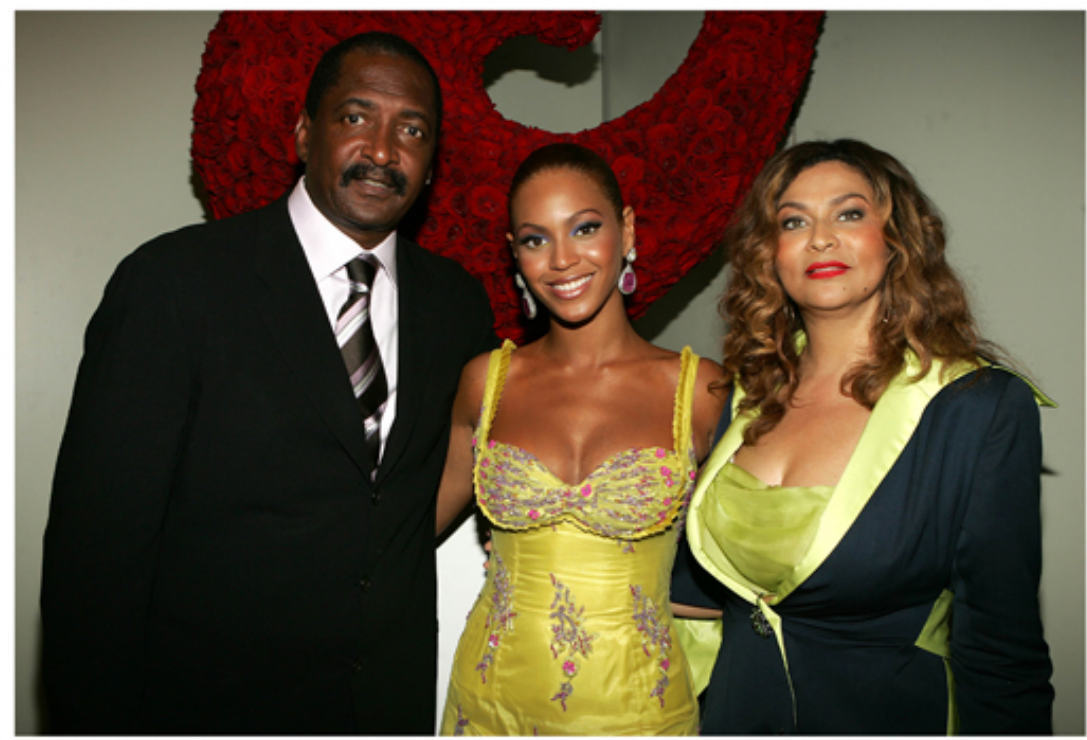

Matthew Knowles, Beyonce, Tina Knowles

Beyoncé's father, Matthew Knowles, was groomed to only date White women and women with light complexions. According to Mr. Knowles, his mother told him not to bring any "nappy" head Black woman into her home. In Mr. Knowles parents' home, colourism was such an issue that he just followed what his parents told him to do. And so, he dated light complexion women. He claimed that he married Beyoncé's mother, Tina Knowles because he thought she was White.

In my opinion, I think it took a long time for Matthew Knowles to realize that judging someone by their skin tone is wrong. He should not allow people to make his life choices on who is and who is not the right person for him to date. Colourism in the Black 
community shows how we try to appeal to European standards and it stops us from being comfortable in our skin.

Lupita Nyong'o, an Oscar Winning Black actress from Kenya, was degraded by former Black basketball player, Gilbert Arenas. Gilbert Arenas said,

"When you say African features black then $u$ have \#1 (Lupita Nyong'o) and she's cute nasenyana) sorry but ewww so the beautiful Black women u try to boost up is technically light skinned or brown skinned" (Rasha, 2017).

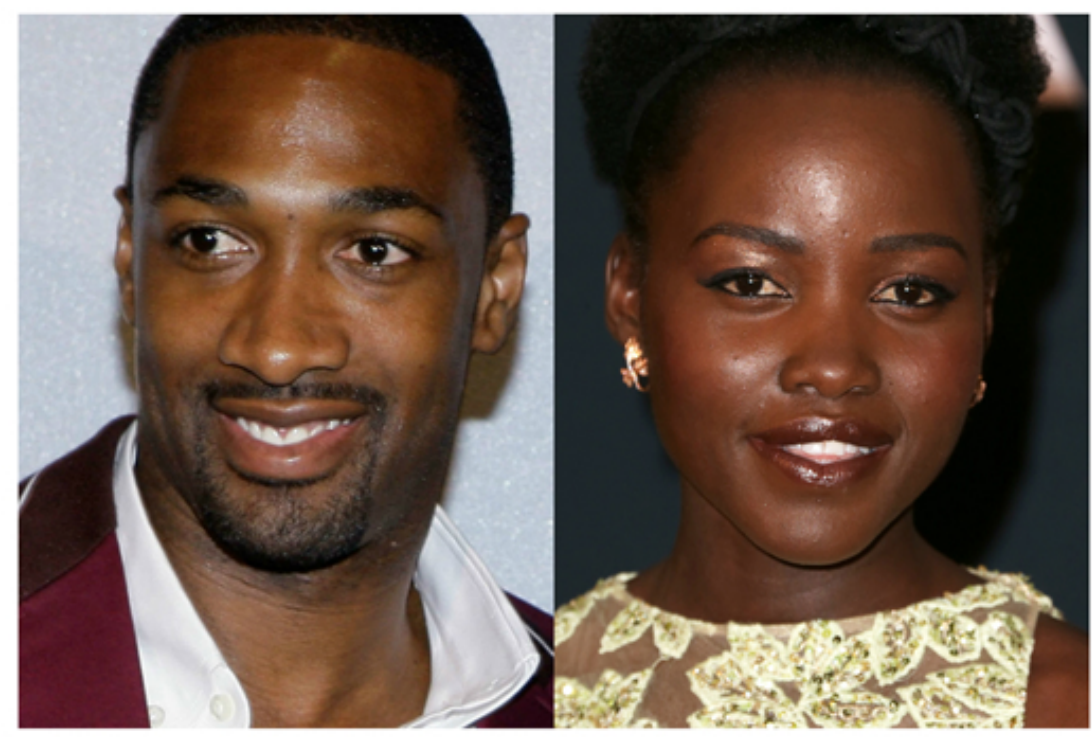

Gilbert Areanas (left) and Lupita Nyong'o (right)

When Gilbert Arenas said this statement, it made it clear that he was not criticizing Lupita Nyong'o for her dark skin. He was not thinking about her accomplishments or contributions to the world of entertainment. Lupita Nyong'o did not allow colourism to impact her life. She is a fashion icon, an Academy Award winner, activist, feminist and author. 
In an interview, Lupita Nyong'o said she was unhappy that some people told her that they like her when she gets angry. Why would someone purposely try to make her angry? I feel like that they want to see her mad because they want to have something negative to talk about. I can recall in class hearing a group of girls and a Black male degrading a Black girl just because of her dark complexion. The Black girl that they were degrading became so infuriated that she cursed all of them. I, on the other hand, felt upset and utterly disgusted because of the way they talked about her. People should want to see Black women succeed rather than be angry.

Some Black women are viewed as angry, ratchet, and uneducated people. They are perceived as angry because some have hypermasculine personalities and are sassy. The 'angry Black woman' trope is a stereotype that highlights Black women as having a hostile temperament. Black women tend to stand for what they believe in and want things to be done a certain way. The term ratchet comes from the anti-Black misogyny. The term misogyny means showing prejudice against Black women. Some Blackwomen are perceived by the White community as ratchet and lacking in social graces. The White society assumes that Blackwomen live in slum areas because of their overall appearance and the fact that some talk in slang. Blackwomen are viewed as uneducated because there is a stigma that they never can finish school and do not work hard.

In 2018, a White photographer named Cameron-James Wilson received backlash for creating a digital Black woman model, Shudu Gram. Black female models felt like he was replacing them for digital models to deny them their jobs. While Cameron-James Wilson claims his digital models are not for profit, I think that his digital models are for financial gain. 


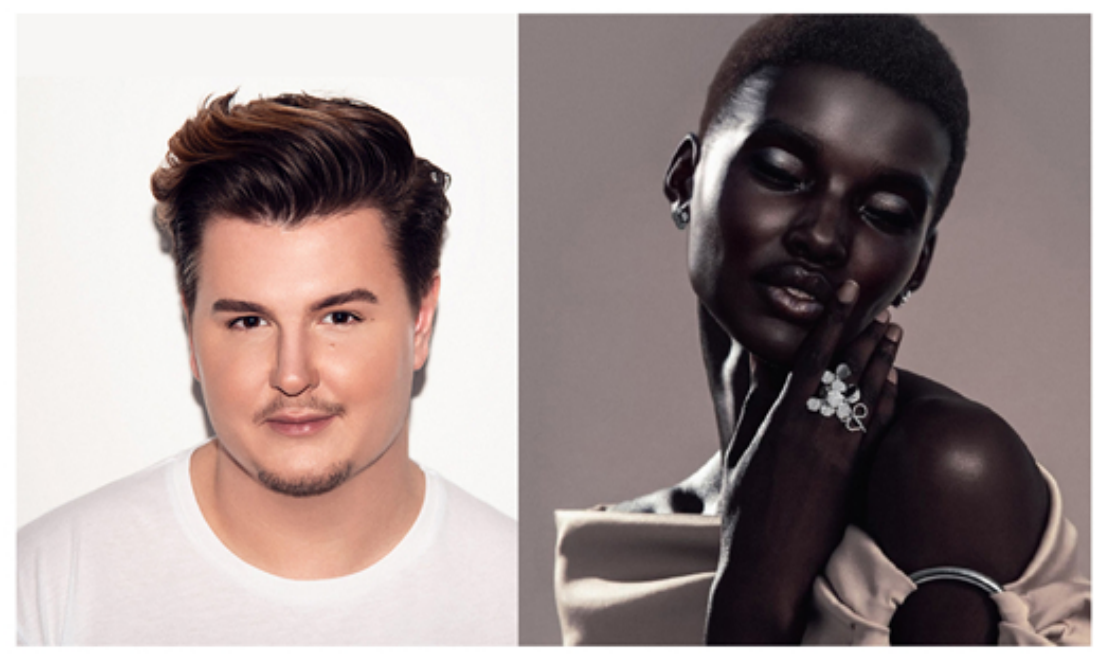

Cameron James-Wilson (left) and Shudu (right)

Cameron James-Wilson has a huge online presence; he is featured in Women's Wear Daily (WWD), Vogue Australia, Vogue Arabia and has also done campaigns for Ellesse and Balmain. He is credited for creating the world's first digital supermodel.
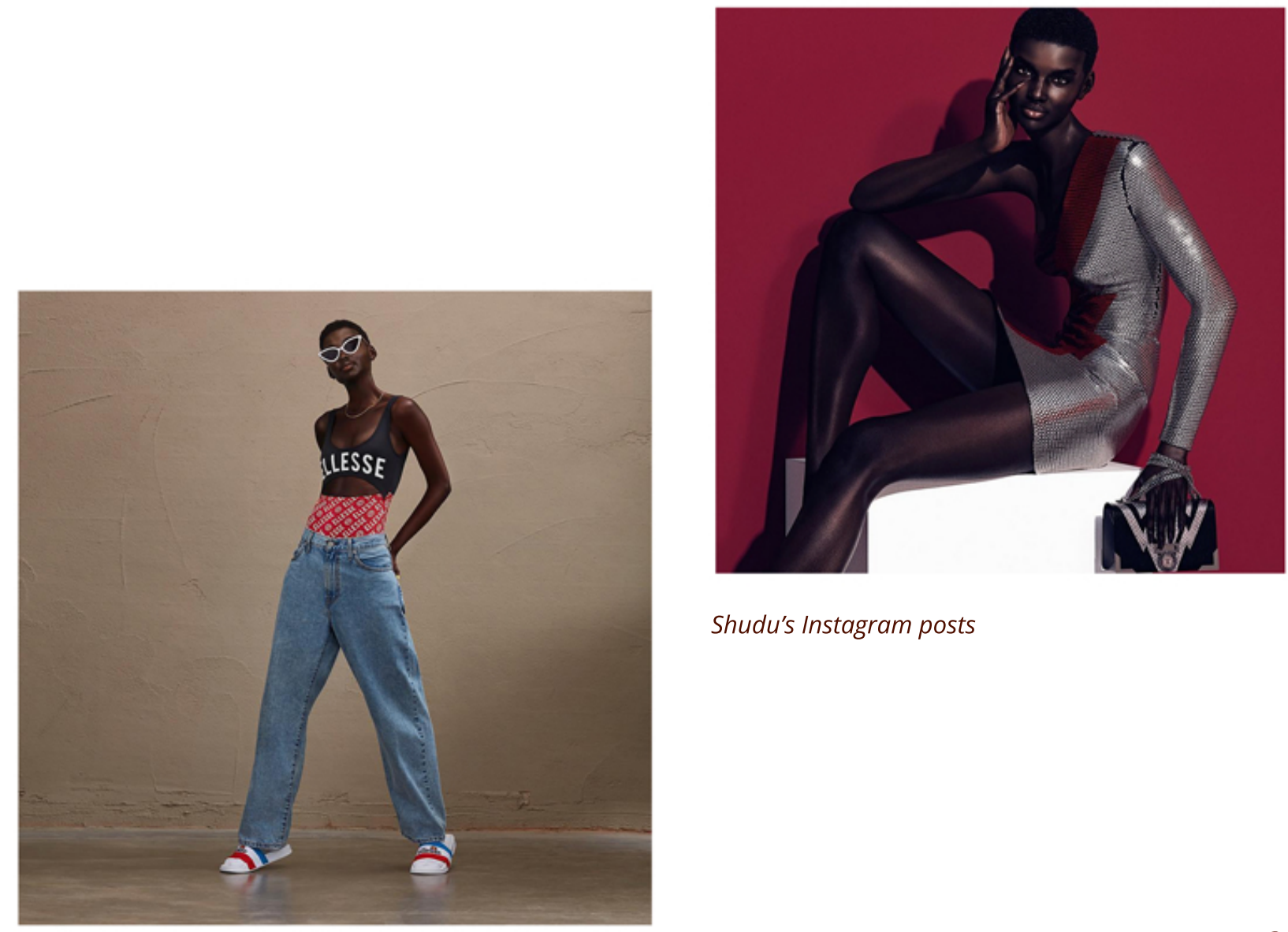

Shudu's Instagram posts 
Black Women such as Solange Knowles raises awareness of Black culture through her songs and music videos. Serena Williams is a famous athlete, Michelle Obama is an activist and role model for Black Women, and Naomi Campbell is a super model in the fashion industry. Black women are skillful beings who are continuously striving to make a difference.

(Clark, fig. 1), (Trusty, fig. 2), (The Editors, fig. 3), (Unknown, fig. 4)
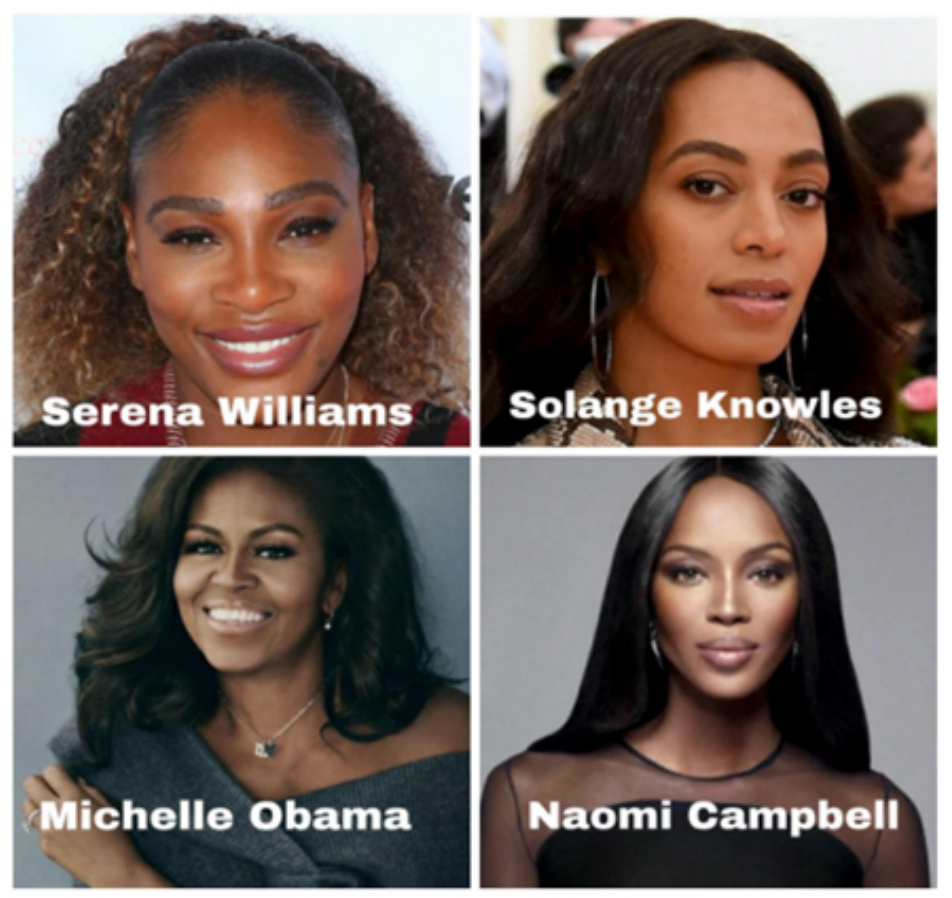

\section{Conclusion}

Black Women have come a long way and need to be recognized in society. They are now being heard and appreciated. Black Women developed hashtags such as Black Twitter, Black excellence, and Black girl magic which highlights the accomplishments and contributions of Black women. Black women are taking a stand within society. They have shown the world that they have a voice. They are confident individuals that are now doing what they want and not feeling like explaining themselves. They are no longer afraid to uplift themselves and each other and have created spaces that revolve around empowerment and liberation. 


\section{References}

Ali, R. (2017, April 14). Gilbert Arenas Says Lupita Nyong'o Is 'Cute When the Lights Are Off' in Rant About Dark-Skinned Women. The Wrap. https://www.thewrap.com/gilbert-arenas-says-lupitanyongo-is-cute-when-the-lights-are-off-in-rant-against-blackwomen/.

Angbeletchy, C. (2020, February 20). Baby Esther: The Harlem singer who made Betty Boop famous. GRIOT. https://griotmag.com/en/ baby-esther-the-harlem-singer-who-made-betty-boop-famous/.

Chen, T. (2018, November 13). A White Teen Is Denying She Is "Posing" As A Black Woman On Instagram After Followers Said They Felt Duped. BuzzFeed News. https://www.buzzfeednews.com/article /tanyachen/white-instagram-teen-emma-hallberg-accused-ofperforming-as.

Chiu, A. (2020, January 9). Jillian Michaels asked why people are 'celebrating' Lizzo's body. Critics slammed her as 'fatphobic.'. The Washington Post. https://www.washingtonpost.com/nation /2020/01/09/jillian-michaels-lizzo-fat-shaming/.

Clark, B. (2020, August 28). Serena Williams has the most extreme masking routine we've ever seen. Serena Williams Shares Her Extreme Nighttime Skin Care Routine | BEAUTY/crew. https://www.beautycrew.com.au/tennis-superstar-serenawilliams-skin-care-obsessed.

Danielle, B. (2016, March 17). This Hairstyle Is Not Called "Boxer Braids" and Kim Kardashian Didn't Make It Popular. Teen Vogue. https://www.teenvogue.com/story/boxer-braids-hairstylehistory.

Dennis, A. (2019, June 5). Colorism: Raising A Dark Skinned Daughter As A Light Skinned Woman In An Anti-Black Society. Medium. https://medium.com/@AngelaDennisWrites/colorism-raising-adark-skinned-daughter-as-a-light-skinned-woman-in-an-antiblack-society-18d9cf3471bd.

Dokosi, M. E. (n.d.). Did you know Betty Boop cartoon character was inspired by Baby Esther but a white imitator claimed ownership? Face2Face Africa. Retrieved June 15, 2021, from https://face2faceafrica.com/article/did-you-know-betty-boopcartoon-character-was-inspired-by-baby-esther-but-a-whiteimitator-claimed-ownership 
Editors, T. (2021, March 10). Michelle Obama Just Shared the One Piece of Advice She'd Give Meghan Markle. Good Housekeeping. https://www.goodhousekeeping.com/life/entertainment/ a25378425/michelle-obama/.

Estrada, M.-S. (2017, June 28). The Fine Line Between Cultural Appropriation And Appreciation. HuffPost Canada. https://www.huffingtonpost.ca/meera-solanki-estrada/the-fineline-between-cultural-appropriation-and-appreciation_a_ 23004529/

Fendrich, H. (2018, September 9). Williams: Umpire treated her differently than a male player. AP NEWS. https://apnews.com/article/ 2fff1a92985d4e73a3106ab0f98049eb

Fidler, J. (2019, November 19). Where are America's 64,000 missing Black Women? The True Crime Times. https://medium.com/the-true-crime-times/where-are-americas64-000-Missing-black-women-6f64fcfb01e5.

Galer, S. S. (2020, April 30). TikTok's darkened skin trend accused of "promoting colourism." BBC News. https://www.bbc.com/news/technology-52487123

Greenstreet, R. (2019, October 12). Lupita Nyong'o: 'The worst thing anyone's said to me? I like it when you're angry.' The Guardian. http://www.theguardian.com/lifeandstyle/2019/oct/12/lupitanyongo-wanted-to-be-botanist

"Health and Working." Teen Vogue, from https://www.teenvogue.com/ story/lizzo-message-weight-health-andworking-out

Hensley, L. (n.d.). 'Blackfishing': A problematic trend where people pretend to be black. Global News. Retrieved June 15, 2021, from https://globalnews.ca/news/4702185/what-is-blackfishing/

Hill, S. (n.d.). Black History Month: Esther Jones, The Original Betty Boop. Retrieved June 15, 2021, from https://www.blackenterprise.com/black-history-month-estherjones-betty-boop/

Howard, M (2018, September 22). (Sara) Saartije Baartman (1789-1815). BlackPast.org. https://www.blackpast.org/global-african-history/ baartman-sara-saartjie-1789-1815/ 
Jackson, L. (2018, May 4). Shudu Gram Is a White Man's Digital Projection of Real-Life Black Womanhood The New Yorker, from https://www.newyorker.com/culture/culture-desk/shudu-gramis-a-whitemans-digital-projection-of-real-life-black-womanhood

Jacobs, T. (2018, September 11). Research Suggests Black Women Are More Likely to Be Objectified and Dehumanized. Pacific Standard. https://psmag.com/social-justice/black-women-aremore-likely-to-be-objectified-and-dehumanized.

Kechiche, Abdellatif (Director and Writer). "Black Venus" (Motion Picture). France: MK2, 20 Oct. 2010

Lee, Spike (Producer, Director \& Writer). "School Daze." (Motion picture). United States: Columbia Pictures, 12 Feb. 1988.

Merret, R. (2018, November 27). "White Influencer Denies She Pretended to Be Black to Get Followers: 'Let Me Explain'." People, from https://people.com/human-interest/white-influencer-deniespretendingto-be-black-for-followers/

McNamara, B. (2020, June 10). "Lizzo posted a powerful Message about Weight, Health and Working out". Condé Nast. https://www.teenvogue.com/story/lizzo-message-weight-health -and-working-out.

Naomi Campbell. The Face Wiki. (n.d.). https://theface.fandom.com/wiki/ Naomi_Campbell.

North, A. (2019, May 3). 'I am a woman and I am fast': what Caster Semenya's story about gender and race in sports. Vox Media. https://www.vox.com/identities/2019/5/3/18526723/castersemenya-800-gender-race-intersex-athletes.

Parkinson, J. (2016, January 7). “The Significance of Sarah Baartman." BBC News, from https://www.bbc.com/news/magazine-35240987

Prasad, R. (2018, September 11). "Serena Williams and the trope of the 'angry black woman.' BBC News, from https://www.bbc.com/ news/world-us-canada-45476500

Prideaux, S. (2019, March 14). "Fashion's Digital Future: How 3D Models and Virtual Clothes Will Soon Become the Norm." The National, from https://www.thenational.ae/lifestyle/fashion/fashion-sdigital-future-how3d-models-and-virtual-clothes-will-soonbecome-the-norm-1.836926 
Razack, S. (2020). Education to expand limitations. Changing the game Women, race, sports, media: When one size doesn't fit all. http://www.teachbeyondaboundary.com/.

Samuels, A. M. (n.d.). BLACK HISTORY MONTH 2016: Beloved cartoon Betty Boop influenced by black Harlem singer Esther Jones. Nydailynews.Com. Retrieved June 22, 2021, from https://www.nydailynews.com/entertainment/black-harlemsinger-inspiration-betty-boop-article-1.2526508

Searles, J. (2019, December 4). How Spike Lee's 'School Daze' Created Film's Most Nuanced Portrait of HBCUs. Thrillist. https://www.thrillist.com/entertainment/nation/spike-leeschool-daze-challenges-racism.

Shudu: The World's First Digital Supermodel. (2019, September 8). The Fashiongton Post. https://fashiongtonpost.com/shudu-gramdigital-supermodel/

The Diigitals Model's // Shudu. (n.d.). Thediigitals. Retrieved June 22, 2021, from https://www.thediigitals.com/shudu

Travis Andrews, A. F. (2019, April 29). Beyoncé's father takes on 'colorism': He dated her mother because he thought she was white. The Washington Post. https://www.washingtonpost.com/news/ morning-mix/wp/2018/02/05/beyonces-father-airs-colorism-he -dated-her-mother-because-he-thought-she-was-white/.

Trusty, B. (2020, April 1). Here's How Much Solange Knowles Is Really Worth. NickiSwift.com. https://www.nickiswift.com/198476/ heres-how-much-solange-knowles-is-really-worth/. 


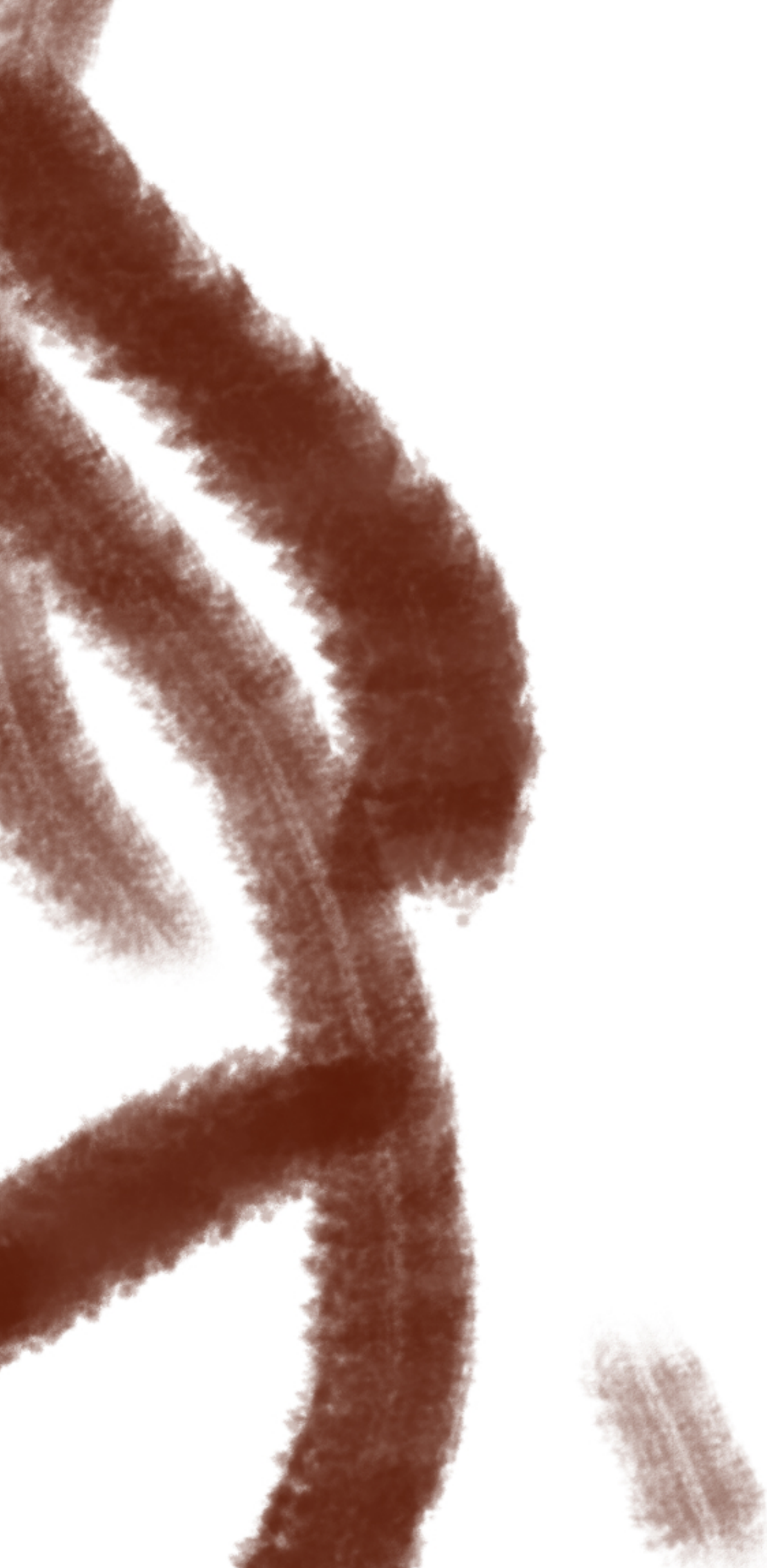

